\title{
Effect of Cooling and Concentrate Feeding on Performances of Karan Fries Cattle under Loose Housing System
}

\author{
Chittapriya Ghosh ${ }^{1}$, Shiv Prasad ${ }^{2}$, Sanjoy Datta ${ }^{3 *}$, Dulal Chandra Roy ${ }^{1}$, \\ Amitava Roy ${ }^{4}$, Shyam Sundar Kesh ${ }^{5}$ and Nirmal Kumar Tudu ${ }^{6}$ \\ ${ }^{1}$ Department of LFC, F/VAS, WBUAFS, India \\ ${ }^{2}$ ADG, ICAR, Krishi Bhavan, New Delhi \\ ${ }^{3}$ Department of $A G B,{ }^{5}$ Department of VCC, ${ }^{6}$ Department of Veterinary Anatomy \\ and Histology, F/VAS, WBUAFS, India \\ ${ }^{4} S M S$ (Animal Science), Murshidabad KVK, WBUAFS, India
}

*Corresponding author

\begin{tabular}{|c|c|}
\hline & A B S T R A C T \\
\hline $\begin{array}{l}\text { Karan Fries, } \\
\text { Cooling, Fod } \\
\text { concentrate r } \\
\text { Milk product }\end{array}$ & \multirow{3}{*}{$\begin{array}{l}\text { Twenty-four Karan Fries cattle in early lactation with good body condition score ( }>3 \text { at } 6 \\
\text { point scale) were allotted four treatments randomly in summer to study the effect of } \\
\text { cooling in combination with altered fodder concentrate ratio on various production } \\
\text { parameters. Provision of cooling as well as higher concentrate allowances significantly } \\
(\mathrm{P}<0.05) \text { improved the nutrients intake of the animals. Composition of various milk } \\
\text { constituents didn't differ significantly }(\mathrm{P}>0.05) \text { by feeding or cooling strategies. Animals } \\
\text { with access to evaporative cooling had greater milk yield than cows with fan alone. } \\
\text { Highest overall milk yield was recorded in T4 group cows }(16.96 \mathrm{Kg} / \mathrm{cow} / \mathrm{day}) \text { followed } \\
\text { by T3, T2 and T1 cows }(15.98,13.99 \text { and } 13.07 \mathrm{Kg} / \mathrm{cow} / \text { day) respectively. In conclusion, } \\
\text { higher concentrate allowances in the ration along with evaporative }(\mathrm{T} 4) \text { cooling system } \\
\text { was the best strategv to maximize nroduction in summer. }\end{array}$} \\
\hline Artic & \\
\hline $\begin{array}{l}\text { Accepted: } \\
\text { 20 November } 2018 \\
\text { Available Online: } \\
10 \text { December } 2018\end{array}$ & \\
\hline
\end{tabular}

\section{Introduction}

One of the greatest challenges to dairy farmers in most part of the tropical country like India is heat stress management in lactating dairy cow. The potential for heat stress exists when air temperature rises above the thermo neutral zone of animals, particularly if humidity is also high. The upper critical temperature for lactating cows is in the range of 24 to $27^{\circ} \mathrm{C}$ (Fuquay, 1981). The Temperature Humidity Index (THI) is commonly used to indicate the degree of stress (Fuquay et al., 1979). When the THI exceeds 72 , high producing dairy cows are affected adversely. Climatic conditions in the most parts of India are such that the warm (or hot) season is relatively long; there is intense radiant energy for an extended period of time and there is generally presence of high relative humidity. Thermal stress has a direct effect on feed intake of the cow, which in turn reduces her milk yield.

The importance of feeding management during lactation period has a direct bearing on the level and efficiency of production. During early lactation, energy intake lags behind milk energy output, a situation which is aggravated 
during summer when feed intake is also reduced by heat stress. The combined effect suppresses the milk production and alters the composition of milk. The energy density of the diet therefore would be of critical importance especially in deciding about the feeding management of high yielding animals through early and mid stages of lactation.

There is no doubt that shelter is one of the cheapest ways to modify micro-environment. Additional cooling in the forms of fans and sprinklers are usually required in combination with forced air sprinkling which increases the loss of heat over sweating alone. Several studies (Berman et al., 1985) have demonstrated upper body sprinkling followed by forced air ventilation to be effective means to reduce body temperature and animal performance.

In the back drop of above information and in view of the fact that most of studies considering influence of and interaction between microclimatic modification and different feeding regimes (post partum) conducted so far pertain to the temperate countries involving European breeds and there are hardly any reports involving crossbreed under tropical environment, whereas response to the feeding may not be same. Keeping these views in mind the present study was carried out to find out the effect of forced air cooling without or with sprinkling on productive performance of Karan Fries (KF) cows under loose housing system and to study the impact of modified microclimate in combination with altered fodder concentrate ratio on various productivity parameters.

\section{Materials and Methods}

\section{Experimental design and management of animals}

The experiment was conducted for 150 days and 24 (twenty four) Karan Fries (KF) cows in early lactation with good body condition ( $>3$ at 6 point scale) from Cattle Yard, National dairy Research Institute, Karnal, Haryana (29.6857 $\mathrm{N}, 76.9905^{\circ} \mathrm{E}$ ) were randomly allotted to four treatments. The cows were in $2^{\text {nd }}$ to $5^{\text {th }}$ parity of lactation. The mean body weight, days in lactation and milk yield of treatment groups were; for $\mathrm{T} 1: 427.0 \mathrm{Kg}, 43.5$ days and 17.16 $\mathrm{Kg}$ /day respectively, for $\mathrm{T} 2: 394.92 \mathrm{Kg}, 39.33$ days and $17.16 \mathrm{Kg} /$ day, respectively, for T3: $387.00 \mathrm{Kg}, 58.5$ days and $17.66 \mathrm{Kg} /$ day, respectively and for $\mathrm{T} 4: 417.50 \mathrm{Kg}, 55.50$ days and $17.75 \mathrm{Kg}$, respectively. The experimental shelter was a loose housing system with head to head arrangements. The shed was having a $45 \mathrm{ft} \times 10 \mathrm{ft}$ central gallery for offering feed to animals and accomplishment of other activities. In each side $45 \mathrm{ft}$ manger space were provided with $2 \mathrm{ft}$ width for 12 animals and 45 $\mathrm{ft} \times 12 \mathrm{ft}$ standing space with a shallow drain (one inch in depth). Over central gallery the height of the roof was $18 \mathrm{ft}$ at the mid rib and over standing space the same was $14 \mathrm{ft}$ with $45^{0}$ slopes on either side. A pressurized distribution system supplied water to lowpressure $180^{\circ}$ brass fabricated mist nozzles, each of which had a $0.5 \mathrm{~mm}$ orifice and was connected to a $68.9 \mathrm{kpa}$ pressure regulator. Twelve nozzles were mounted at $1 \mathrm{~m}$ intervals in an iron pipe at a height of $2.8 \mathrm{~m}$. The evaporative sprinklers were angled such that the bulk of sprinkle was on back and midpoint of the cow. One ceiling fan (for six cows) on each side was also fixed above the iron pipe each with $1400 \mathrm{~mm}$ blade size, $280 \mathrm{rpm}$, and 75 watt motors and supplying airflow of 17100 $\mathrm{m}^{3} / \mathrm{h}$. The fans were fitted at an angle of $20^{\circ}$ and placed at $3 \mathrm{~m}$ apart and $3 \mathrm{~m}$ high. The system combining fan and sprinklers were sequentially activated to repeat cycle of wetting and ventilation for seven periods of 0.5 hour at 1.5-2 hour intervals between 07.30 AM and 7.30 PM during entire period of summer. Cows in shed with fans (for T1 and T2) were provided with fan alone and shed with evaporative cooling (for T3 and T4) was fitted 
with above specified cooling systems. Besides getting stipulated cooling regimes, all of the experimental animals were exposed to water splashing for 7-10 minutes before starting of each milking. The cows of $\mathrm{T} 1$ and $\mathrm{T} 3$ groups received $40 \%$ of their energy requirements through concentrate and $\mathrm{T} 2$ and $\mathrm{T} 4$ groups received $50 \%$ of their energy requirements through concentrate. All of the experimental animals had accessed of adlib seasonal green fodder (maize). The animals were fed as per NRC, 1989. The concentrate mixture $(21 \% \mathrm{CP}$ and $70 \% \mathrm{TDN}$ ) contain $40 \%$ maize, $30 \%$ rice bran, $27 \%$ mustard cake, $2 \%$ mineral mixture and $1 \%$ salt. Concentrate was fed in three installments during milking time. Group wise fodder (maize) intake was monitored on daily basis. In addition, fodder intakes of individual cows within groups were also measured on fortnightly basis on two consecutive days and the average intakes were used for proportionate allocation for arriving at individual cow fodder intake during the respective fortnight.

\section{Parameters recorded for study}

Various components of climate were studied in two sides of shelter (SF-Shed with fans and SEC-Shed with evaporative cooling) for each day and fortnight wise mean were calculated. Maximum (max), minimum (min), Dry bulb (Db), Wet bulb (Wb) temperatures were recorded by suitable thermometer. Relative humidity \% (RH\%) was calculated from dry and wet bulb temperature by using web-based program available on www.weather.gov provided by National Weather Forcast Service Office, El Paso area. The observation for recording climatic components was made twice a day i.e., at $07.22 \mathrm{hrs}$ IST and 14.22 hrs, IST i.e., at 7.00 AM and 2.00PM (Local mean time), as they represent approximately the epochs of various climatic variables. Rectal temperature (using clinical thermometer), skin temperature (using digital Royteck instrument at four points) respiration rate (by counting the movement of flanks) and pulse rate (counted by palpating coccigeal artery) of all the animals were recorded at 7.30 $\mathrm{AM}$ and $3.30 \mathrm{PM}$ at 15 days interval. Composite sample of green fodder (maize) and concentrate were analyzed for DM and proximate compositions (AOAC, 1990) fortnightly. TDN content of fodder as well as concentrate was calculated from their proximate composition using equation specified by (Wardeh, 1981). The samples of milk were taken initially at the start of experiment then at fortnightly intervals till the end of experiment. The samples of milk of individual milking were stored at refrigerated temperature overnight and were tested for (i) fat using milk tester (REIL, Jaipur) having accuracy of \pm 0.06 , (ii) protein was determined by Kjeldahl method as per AOAC (1995). Corrected lactometer reading (CLR) was used for calculating solids-not-fat (SNF). Daily milk yield was recorded and 4\% FCM milk yield was calculated as per formulae (Tyrell and Reid, 1965). All animals were screened fortnightly for detection of sub clinical mastitis by Modified California Mastitis Test (MCMT) according to Sastry (1978) and Somatic cell counts (SCC) as per method mentioned in IDF bulletin, No.168, 1984. Body weight of each animal was recorded initially and then at fortnightly intervals in the morning before feeding. For recording BCS the scoring chart on 1-6 scale (Prasad, 1994) was used. Blood glucose (at the start of experiments and then 45 days interval) was determined by colorimetric (O-Toluidine) method given by using glucose detection kits supplied by Nice chemicals. Various efficiency parameters (FCMY/TDNI, FCMY/CPI and GE \%) were calculated as per Brody, 1945.

\section{Statistical analysis}

Average and variability of different parameters were estimated as per standard procedure. The effect of shelter components 
were analyzed through Least-squares analysis (Harvey, 1987). Significant means were compared by Fischer's LSD. The following model was used to study the effect of fodderconcentrate ratio and microclimate on various nutritional, physical and production parameters.

$\mathrm{Y}_{\mathrm{ijk}}=\mu+\mathrm{F}_{\mathrm{i}}+\mathrm{M}_{\mathrm{j}}+\mathrm{FM}_{\mathrm{ij}}+\mathrm{E}_{\mathrm{ijk}}$

$\mu=$ Overall mean

$\mathrm{F}_{\mathrm{i}}=$ Effect of $\mathrm{i}^{\text {th }}$ fodder-concentrate ration $(\mathrm{i}=1,2)$

$\mathrm{M}_{\mathrm{j}}=$ Effect of $\mathrm{j}^{\text {th }}$ microclimate $(\mathrm{j}=1$ : Fans, 2 : Fans + Sprinklers)

$\mathrm{FM}_{\mathrm{ij}}=$ Interaction between $\mathrm{F}_{\mathrm{i}}$ and $\mathrm{M}_{\mathrm{j}}$

$\mathrm{E}_{\mathrm{ijk}}=$ Random error

\section{Results and Discussion}

\section{Climatic variables}

The results showed that SEC had lower max $(\mathrm{P}<0.05)$ and $\min (\mathrm{P}>0.05)$ temperatures than SF. Furthermore, the SEC had significantly lower $\mathrm{Db} \quad(\mathrm{P}<0.01)$ and $\mathrm{Wb}$ temperature $(\mathrm{P}<0.05), \quad$ THI (morning, $\quad \mathrm{P}<0.05$ and afternoon, $\mathrm{P}<0.01)$ during morning and afternoon hours but significantly $(\mathrm{P}<0.01)$ higher $\mathrm{RH} \%$ during morning and afternoon hours than that of SF shed. Mean $( \pm S E)$ for various climatic variables of experimental shelters have been presented in Table 1 .

The temperature humidity index is commonly used to denote the degree of stress in dairy cattle. At a THI above 72, heat stress has been reported to be sufficient to decrease the milk yield (Johnson et al., 1963), depression in milk yield being more pronounced when THI exceeded 76. In the present study also, the cows kept in SF (T1) were adversely affected by heat stress. A previous study (Taylor et al., 1991) that determined climatic conditions in treatment pens showed that the EC system reduced maximum daily temperature by $5.6^{\circ} \mathrm{C}$ and reduced average THI by 2.3 units. Hsu and Liu (1996) reported that an increase of the
THI in the experimental farm had significant adverse effects on milk yield (16.1 versus 13.9 $\mathrm{kg} /$ day, during hot versus cool season). Ravagnolo et al. (2000) reported that maximum temperature and minimum relative humidity were the most critical variables to quantify heat stress and both these variables can easily be combined into THI. Milk yield declined@0.2 kg per unit increase in THI when THI exceeded 72.

\section{Physiological indices}

The results showed that microclimate (MC) had significant $(\mathrm{P}<0.01)$ effect on all physiological indices but fodder-concentrate ratio $(F: C)$ didn't have significantly effect on the same $(\mathrm{P}>0.05)$.

The experimental data showed that (Table 3) cows under different treatment groups had higher values of RR, HR, RT and ST during afternoon, because in afternoon hours THI was higher in both shelters as compared to morning hours (SF, 76.41 vs. 83.80 and SEC, 74.61 vs. 79.16). Diurnal variations in non cooled (T1 and T2) groups were more pronounced than evaporative cooling (T3 and T4) cows because SF group animals had higher THI both in morning and afternoon hours than SEC animals. The significant decrease $(\mathrm{P}<0.01)$ in $\mathrm{RT}$ and $\mathrm{RR}$ of cows showed that partial alleviation of heat stress resulted from evaporative cooling, the effect of which was subsequently confirmed by increased milk production and reduction of BW loss.

In our study, the data suggests that EC was not sufficient to completely eliminate heat stress in cows because morning and afternoon THI (74.61 and 79.76) remained high enough to depress milk yield as also reported in previous research findings. However, THI might not accurately reflect heat stress in EC system that deliver a pressurized spray with considerable air movement above the cow's back, causing a 
strong cooling effect. A similar finding was also reported by Tarzon et al., (1999) in evaporative cooled cows. These findings are consistent with those of previous studies (Taylor et al., 1991 and Chen et al., 1993). In their study, protein quality didn't affect RT or RR of cows but EC significantly decreased both RT and RR compared to animals kept in shade only. Similarly, Florida workers reported an $11.6 \%$ improvement in milk yield when cows were sprayed for $1.5 \mathrm{~min}$ of every 15 min of operation (Strickland et al., 1988). Cooled cows had sharply reduced respiratory rate (57 versus 95 breaths/min), and better efficiency of production ( $\mathrm{kg}$ milk per $\mathrm{kg}$ DMI), probably due to lower energy expenditures for body cooling. Day long cooling in the free stall barn provides for continuous cooling, minimizing the elevation of body temperature during the daytime. Several studies have confirmed that the evaporative cooled cows have lower RT and ST and HR and RR than those that were not cooled (Armstrong, 1983 and Ryan et al., 1992).

\section{Nutritional parameters}

The microclimate and fodder concentrate ration $(\mathrm{F}: \mathrm{C})$ had significant effect on various nutritional parameters (FODDMI, FODDMI/100 Kg BW, CONDMI, CONDMI/100 Kg BW, DMI, DMI/100 Kg BW, TDNI, TDNI/100 Kg BW, CPI and $\mathrm{CPI} / 100 \mathrm{Kg} \mathrm{BW}$ ) where as interaction of these treatment factors found significant for some of the parameters (Table 2).

It has been discussed earlier that SEC provides better microclimate and strong cooling effect to maintain normal physiological homeostasis in summer than inside the shed only fitted with fans (SF). SF was not sufficient to alleviate heat stress during summer months in northern part of India. Cows under T1 and T2 consumed less DM through fodder as well as overall DM. This phenomenon was more pronounced in $\mathrm{T} 1$ which showed lowest DMI/100 Kg BW (2.67 Kg/100 Kg BW). The animals in T2 compensated DMI to some extent because they got greater concentrate allowance in ration. Highest DMI was observed in T4 $(12.50 \mathrm{Kg} /$ cow/day), where cows got the better microclimate as well as the higher concentrate allowance. In the $\mathrm{T} 2$ and T4 groups kept under SF and SEC, respectively, as concentrate allowances increased in feeding plan, the dry matter intake through fodder got decreased. Higher TDNI in groups kept under SEC (T3 and T4) as compared to treatment group under SF (T1 and T2) was mainly due to the absence of heat stress in SEC, which favored higher DMI. So, energy was one of the limiting factors for the cows which were not cooled by water sprinkling during heat stress, particularly when cows were in early or mid stage of lactations.

These findings are consistent with the results of previous studies. Feed intake in lactating cattle begins to decline at ambient temperatures of $25-26^{\circ} \mathrm{C}$ and drops more rapidly above $30^{\circ} \mathrm{C}$. Heat stress causes the rostral cooling centre of the hypothalamus to stimulate the medial satiety center which inhibits the lateral appetite center, resulting in reduced dietary intake and consequently lower milk production (Albright and Alliston, 1972). Heat stress in high producing cows results in dramatic reduction in roughage intake and rumination (Collier et al., 1982). The reduction in appetite under heat stress is a result of elevated body temperature and may be related to gut fill. Most of the earlier workers reported lower RT, RR but higher DMI for cows receiving evaporative cooling than for cows in shed alone or under shed plus fan management system (Flamenbaum et al., 1995 and Chan et al., 1997). Cooling may directly influence milk secretion from mammary gland, but its primary effect is to restore feed intake that has been suppressed due to elevated level of heat stress. 
From the above results it can be safely inferred that, effect of heat stress can be minimized by providing sequential sprinkling along with sufficient supplementary air flow. Though increasing energy density in diet provide one option to maintain DM intake but in isolation it may not be sufficient to sustain optimum production in hot environment.

\section{Physical parameters}

The results revealed that both the feeding and microclimatic treatment factors had non significant $(\mathrm{P}>0.05)$ effect on all of physical parameters under study (BCS, change of BCS and change of $\mathrm{BW}$ ).

The findings of the present study are at some variance to the results of earlier findings. In the present study fodder-concentrate ratio didn't affect the BCS, CHBCS and CHBW significantly $\quad(\mathrm{P}>0.05)$. Sprondly (1986) concluded that changing the ratio of roughage to concentrate from $62: 38$ to $50: 50$ significantly increased FCMY and live weight gain. Raising the concentrate levels $(50,65$ and $80 \%$ ) in the diet led to increased net energy intake $(\mathrm{P}<0.01)$; cows tended to gain more weights and negative energy balance declined ( $\mathrm{P}<0.01)$. Mahal et al., (1997) reported no differences in the live weight changes at forage-concentrate ratios of 50:50, 60:40 and 70:30. Parvinder (1997) concluded that rations having similar TDN and $\mathrm{CP}$ but differing in green fodder proportions $(15,30$ and 60 percent as fodder) behave nearly alike from BCS point of view during early lactation in crossbred cows.

In summer though the effect of microclimate (MC) didn't reach the level of significance $(\mathrm{P}>0.05)$, the groups under SEC (T3 and T4) receiving evaporative cooling (EC) showed better overall and final BCS (Fig. 1). Animals under T2 group showed lowest BCS; actually they started with low BCS at the beginning of experiment. Animals under T4 (EC + 50\% concentrate proportion in ration) showed better overall and final BCS. None of the treatment groups showed excessive loss of BW and BCS during any point of study possibly because all animals received supplementary air flow (fans) continuously during hot summer season. Armstrong et al., (1986), similar to these findings also observed that mist cooling increased the mean BW of cows over 5 months study period in hot arid climate.

\section{Blood glucose level}

The blood glucose level was affected significantly by both the treatment factors (F:C and MC). Highest blood glucose level was noted in T4 $(52.42 \pm 0.62 \mathrm{mg} / \mathrm{dL})$. The higher nutrient intake, better BCS and BW gain in T4 was reflected on blood glucose levels. Lowest values of blood glucose were noted in $\mathrm{T} 1 \quad(49.58 \pm 0.58 \mathrm{mg} / \mathrm{dL})$ as their nutrient intake/100 Kg BW was lowest among all treatment groups. Animals receiving higher proportion of concentrate in ration of SF (T2) showed blood glucose value compatible with cooled cows. Higher intake of DM and energy in T2 group was most likely responsible for this trend.

Cooling and higher concentrate proportion in ration was beneficial to express normal metabolic profile. These findings corroborate well with other research findings. Experimentation on Holstein cows were taken to study the effect of five dietary forage to concentrate ratios on blood constituents and production characteristics (Dhiman et al., 1991). Increasing forage in the diet from 38 percent to 98 percent increased $\beta$ hydroxy butyrate and decreased glucose in plasma during early lactation. Armstrong et al., (1988) found higher plasma thyroxin and glucose level in evaporative cooled cows. 


\section{Milk production and compositions}

The results revealed that F:C did not affect the milk yield of the experimental groups of cows significantly $(\mathrm{P}>0.05)$ but $\mathrm{MC}$ had significant effect $(\mathrm{P}<0.01)$ on milk yield. Interactions of these two factors (F:C X MC) on milk production also was non significant $(\mathrm{P}>0.05)$. Percentage of various milk constituents (Table 4) didn't differ significantly among four groups but fortnightly milk compositional yield (Fortnightly fat (FFY), protein (FPY), solids not fat (FSNFY) and Total solids (FTSY) yield) increased significantly $(\mathrm{P}<0.01)$ due to EC.

Forage to concentrate ratio was recognized to influence milk composition especially milk fat content. Thomas and Martin (1988) concluded from various studies on forage concentrate ratio and reported that the milk fat got depressed as the proportion of concentrate diet increased. On the basis of these studies, it was concluded beyond 60 percent level of concentrate feeding any additional concentrate begins substantially to depress milk fat content.

On the other hand, milk protein is relatively more stable milk constituent than milk fat and shows lesser tendency to change with feeding treatments. Allowances of starchy concentrate were reported to increase milk protein. Sutton (1989) after extensively reviewing the pertinent literature reported that increasing energy intake was effective in increasing milk protein. Forage to concentrate ratio and type of carbohydrate in the concentrate was also shown to effect protein in some studies but the response in general was inconsistent. Furthermore, dietary protein had little or no effect on protein concentration in milk.

These results are in agreement with the present findings showing non-significant effect of different forage proportion on milk protein and overall composition of milk. In present study all of the treatments groups received adlib green fodder and their forageconcentrate ratio varied within normal range in both the experiments. These factors were primarily responsible for non significant effect of forage-concentrate ratio on various milk constituents. Furthermore EC has no effect on milk constituents. Other researchers have also shown little or no effect of evaporative cooling on percentage of milk components (Armstrong et al., 1988 and Chen et al., 1993).

The highest TOTFORMY and FFCMY were observed in T4 group, followed by T3, T2 and T1. Though the effect of F:C was non significant $(\mathrm{P}>0.05)$ but higher milk yield was observed for the groups supplemented with higher proportion of concentrate in ration (T1 vs T2 and T3 vs T4) kept under same shelters. Microclimate significantly affected both the milk yield parameters. The treatment groups kept under SEC (T3 and T4) had better overall performances than the groups kept under SF. Higher nutrient (DM, CP and TDN) intake of evaporative cooled cows were reflected on their milk production performances. Though no interaction was found in between two factors (F:C X MC) but treatment group (T4) receiving $\mathrm{EC}$ and higher concentrate allowances produced highest milk yield.

Milk production during initial fortnights reached the level of significance among four treatment groups but there after the difference was not so marked. In our studies, during early lactation better overall production and nutrient utilization (Fig. 2) was observed in cows that received EC than cows that received only fans.

In SF heat stress adversely affected milk production particularly during early phase of lactation. So, the provision of fans alone in shed was not sufficient to minimize heat stress in the study and the additional cooling in the forms of fans and sprinklers were needed. 
The beneficial effects of EC as observed in this study are consistent with results of other studies. In combination with forced air, sprinkling increases the loss of heat over the possible sweating alone. Several studies
(Berman et al., 1985) had demonstrated upper body sprinkling followed by forced air ventilation to be effective means to reduce body temperature and animal performance.

Table.1 Components of various climatic variables in two modified shelters

\begin{tabular}{|l|l|l|}
\hline & SF & SEC \\
\hline Max & $38.96 \pm 0.34^{\mathrm{a}}$ & $36.19 \pm 0.31^{\mathrm{b}}$ \\
\hline $\mathbf{M i n}$ & $26.32 \pm 0.24$ & $25.79 \pm 0.23$ \\
\hline $\mathbf{D b}_{\mathbf{m}}$ & $26.78 \pm 0.20^{\mathrm{A}}$ & $24.97 \pm 0.21^{\mathrm{B}}$ \\
\hline $\mathbf{D b}_{\mathbf{e}}$ & $32.48 \pm 0.29^{\mathrm{A}}$ & $28.71 \pm 0.24^{\mathrm{B}}$ \\
\hline $\mathbf{W b}_{\mathbf{m}}$ & $22.96 \pm 0.20^{\mathrm{a}}$ & $22.27 \pm 0.21^{\mathrm{b}}$ \\
\hline $\mathbf{W b}_{\mathbf{e}}$ & $26.83 \pm 0.24^{\mathrm{a}}$ & $25.69 \pm 0.22^{\mathrm{b}}$ \\
\hline $\mathbf{R H}_{\mathbf{m}} \%$ & $72.57 \pm 0.63^{\mathrm{A}}$ & $79.29 \pm 0.47^{\mathrm{B}}$ \\
\hline $\mathbf{R H}_{\mathbf{e}} \%$ & $65.77 \pm 0.89^{\mathrm{A}}$ & $79.19 \pm 0.76^{\mathrm{B}}$ \\
\hline $\mathbf{T H I}_{\mathbf{m}}$ & $76.41 \pm 0.28^{\mathrm{a}}$ & $74.61 \pm 0.30^{\mathrm{b}}$ \\
\hline $\mathbf{T H I}_{\mathbf{e}}$ & $83.80 \pm 0.36^{\mathrm{A}}$ & $79.76 \pm 0.32^{\mathrm{B}}$ \\
\hline
\end{tabular}

SF-Shed with fans, SEC-shed with evaporative cooling, Max-Maximum, Min-Minimum, Db-Dry bulb, Wb-Wet bulb temperatures in ${ }^{0} \mathrm{C}$. RH\%-Relative humidity\%, THI-Thermal humidity index and $\mathrm{m} / \mathrm{e}-\mathrm{M}$-Morning/Evening.

Treatment bearing different superscripts within row differ significantly $\left({ }^{\mathrm{ab}} \mathrm{P}<0.05\right.$ and $\left.{ }^{\mathrm{AB}} \mathrm{P}<0.01\right)$.

Table.2 Effect of microclimate and level of concentrate feeding on various nutritional, physical parameters and blood glucose level of crossbred cows

\begin{tabular}{|c|c|c|c|c|}
\hline & \multicolumn{4}{|c|}{ Groups } \\
\hline Parameters & T1 & T2 & T3 & $\mathrm{T} 4$ \\
\hline FODDMI (Kg/day/cow) & $6.24 \pm 0.09^{\mathrm{a}}$ & $5.66 \pm 0.08^{b}$ & $6.58 \pm 0.09^{c}$ & $6.30 \pm 0.08^{c}$ \\
\hline FODDMI/100 Kg BW & $1.495 \pm 0.020^{\mathrm{a}}$ & $1.496 \pm 0.018^{\mathrm{a}}$ & $1.705 \pm 0.020^{b}$ & $1.511 \pm 0.017^{\mathrm{a}}$ \\
\hline CONDMI (Kg/day/cow) & $4.89 \pm 0.09^{\mathrm{a}}$ & $5.48 \pm 0.07^{b}$ & $5.27 \pm 0.11^{b}$ & $6.20 \pm 0.73^{c}$ \\
\hline CONDMI/100 Kg BW & $1.177 \pm 0.021^{\mathrm{a}}$ & $1.453 \pm 0.022^{b}$ & $1.376 \pm 0.032^{\mathrm{c}}$ & $1.483 \pm 0.029^{b}$ \\
\hline DMI (Kg/day/cow) & $11.13 \pm 0.15^{\mathrm{a}}$ & $11.14 \pm 0.09^{\mathrm{a}}$ & $11.85 \pm 0.12^{\mathrm{b}}$ & $12.50 \pm 0.17^{\mathrm{c}}$ \\
\hline DMI/100 Kg BW & $2.67 \pm 0.03^{\mathrm{a}}$ & $2.95 \pm 0.03^{b}$ & $3.08 \pm 0.04^{\mathrm{c}}$ & $3.00 \pm 0.04^{c}$ \\
\hline TDNI (Kg/day/cow) & $7.80 \pm 0.11^{\mathrm{a}}$ & $7.66 \pm 0.70^{\mathrm{a}}$ & $8.10 \pm 0.09^{b}$ & $8.57 \pm 0.12^{b}$ \\
\hline TDNI/100 Kg BW & $1.823 \pm 0.023^{\mathrm{a}}$ & $2.027 \pm 0.020^{\mathrm{b}}$ & $2.052 \pm 0.028^{\mathrm{c}}$ & $2.106 \pm 0.025^{c}$ \\
\hline CPI (Kg/day/cow) & $1.64 \pm 0.03^{\mathrm{a}}$ & $1.71 \pm 0.02^{\mathrm{ab}}$ & $1.76 \pm 0.02^{b}$ & $1.93 \pm 0.03^{\mathrm{c}}$ \\
\hline $\mathrm{CPI} / 100 \mathrm{Kg} \mathrm{BW}$ & $0.394 \pm 0.005^{\mathrm{a}}$ & $0.454 \pm 0.005^{\mathrm{b}}$ & $0.470 \pm 0.007^{\mathrm{b}}$ & $0.477 \pm 0.007^{b}$ \\
\hline Fodder $\%$ in ration & $56.03 \pm 0.50^{\mathrm{a}}$ & $50.78 \pm 0.54^{\mathrm{b}}$ & $55.59 \pm 0.64^{\mathrm{a}}$ & $50.63 \pm 0.57^{b}$ \\
\hline CHBW (Kg/cow/fortnight) & $-0.717 \pm 1.407$ & $-0.657 \pm 1.295$ & $0.310 \pm 1.646$ & $0.022 \pm 8.081$ \\
\hline CHBCS (Unit/cow/fortnight) & $-0.007 \pm 0.026$ & $-0.046 \pm 0.054$ & $0.07 \pm 0.032$ & $0.020 \pm 0.045$ \\
\hline Overall BCS & $3.34 \pm 0.06$ & $3.16 \pm 0.06$ & $3.37 \pm 0.020$ & $3.44 \pm 0.14$ \\
\hline Blood glucose level (I & $49.85 \pm 0.58^{\mathrm{a}}$ & $51.40 \pm 0.61^{\text {ab }}$ & $51.41 \pm 0.67^{\mathrm{ab}}$ & $52.42 \pm 0.62^{b}$ \\
\hline
\end{tabular}

DMI-Dry matter intake, CHBW-Change of body weight and CHBCS-Change of body condition score, CPI-Crude protein intake, TDNI-Total Digestible nutrient intake. FODDMI-Dry matter intake through fodder and CONDMIDry matter intake through concentrate. Treatment means bearing different superscripts within same row differ significantly $(\mathrm{P}<0.05)$. NS-Non significant $(\mathrm{P}>0.05)$. 
Table.3 Physiological indices of crossbred cows under different cooling and concentrate feeding strategies in summer

\begin{tabular}{|c|c|c|c|c|}
\hline Parameters & T1 & $\mathrm{T} 2$ & T3 & $\mathrm{T} 4$ \\
\hline $\mathbf{R R}_{\mathrm{m}}(\mathbf{c p m})$ & $32.75 \pm 1.18^{\mathrm{abA}}$ & $34.89 \pm 1.11^{\mathrm{aA}}$ & $30.93 \pm 1.06^{\mathrm{bcA}}$ & $29.59 \pm 0.82^{\mathrm{cA}}$ \\
\hline $\mathbf{R R}_{\mathrm{e}}(\mathbf{c p m})$ & $60.05 \pm 1.72^{\mathrm{aB}}$ & $59.32 \pm 2.32^{\mathrm{aB}}$ & $35.90 \pm 1.19^{\mathrm{bB}}$ & $38.57 \pm 1.44^{\mathrm{bB}}$ \\
\hline$H_{R_{m}}(\mathrm{bpm})$ & $66.22 \pm 1.02^{\mathrm{A}}$ & $69.39 \pm 1.02^{\mathrm{A}}$ & $65.83 \pm 1.30^{\mathrm{A}}$ & $66.48 \pm 0.79^{\mathrm{A}}$ \\
\hline$H_{R_{e}}(\mathrm{bpm})$ & $79.83 \pm 1.25^{\mathrm{aB}}$ & $80.31 \pm 1.11^{\mathrm{aB}}$ & $72.72 \pm 1.05^{\mathrm{bB}}$ & $71.17 \pm 1.00^{\mathrm{bB}}$ \\
\hline $\mathbf{R T}_{\mathrm{m}}\left({ }^{\mathbf{0}} \mathrm{C}\right)$ & $39.13 \pm 0.08^{\mathrm{aB}}$ & $38.07 \pm 0.06^{\mathrm{bA}}$ & $38.01 \pm 0.05^{\mathrm{bA}}$ & $38.00 \pm 0.05^{\mathrm{bA}}$ \\
\hline $\mathrm{RT}_{\mathrm{e}}\left({ }^{0} \mathrm{C}\right)$ & $39.13 \pm 0.08^{\mathrm{aB}}$ & $38.92 \pm 0.09^{\mathrm{bB}}$ & $38.19 \pm 0.16^{\mathrm{cB}}$ & $38.32 \pm 0.06^{\mathrm{cB}}$ \\
\hline $\mathrm{ST}_{\mathrm{m}}\left({ }^{\mathbf{0}} \mathrm{C}\right)$ & $35.27 \pm 0.15^{\mathrm{A}}$ & $35.45 \pm 0.14^{\mathrm{A}}$ & $35.55 \pm 0.14$ & $35.61 \pm 0.14$ \\
\hline $\operatorname{STe}\left({ }^{0} \mathrm{C}\right)$ & $37.31 \pm 0.20^{\mathrm{aB}}$ & $37.04 \pm 0.20^{\mathrm{aB}}$ & $35.62 \pm 0.20^{b}$ & $36.02 \pm 0.20^{b}$ \\
\hline
\end{tabular}

Treatment means with different alphabets ${ }^{\text {abc }}$ as superscripts within same row differ significantly $(\mathrm{P}<0.01)$.

Treatment means with different superscripts under different row and same column (within fortnight) differ significantly $(\mathrm{P}<0.05)$.

Table.4 Effect of microclimate and level of concentrate feeding on milk production, compositions, efficiency and economic benefits of crossbred cows

\begin{tabular}{|c|c|c|c|c|}
\hline & \multicolumn{4}{|c|}{ Groups } \\
\hline Parameters & $\mathbf{T 1}$ & $\mathbf{T} 2$ & T3 & $\mathrm{T} 4$ \\
\hline TOTFORMY (Kg/cow) & $196.08 \pm 5.70^{\mathrm{a}}$ & $209.82 \pm 4.60^{\mathrm{a}}$ & $239.71 \pm 6.90^{b}$ & $250.45 \pm 9.05^{b}$ \\
\hline FFCMY (Kg/cow) & $204.89 \pm 5.30^{\mathrm{a}}$ & $215.13 \pm 4.69^{a}$ & $251.59 \pm 7.32^{b}$ & $262.01 \pm 9.12^{b}$ \\
\hline Fat $\%$ & $4.34 \pm 0.04$ & $4.18 \pm 0.05$ & $4.34 \pm 0.06$ & $4.33 \pm 0.06$ \\
\hline FFY (Kg/cow) & $8.43 \pm 0.21^{\mathrm{a}}$ & $8.75 \pm 0.20^{\mathrm{a}}$ & $10.38 \pm 0.32^{b}$ & $10.79 \pm 0.38^{b}$ \\
\hline Protein \% & $3.14 \pm 0.03$ & $3.15 \pm 0.13$ & $3.18 \pm 0.02$ & $3.18 \pm 0.02$ \\
\hline FPY (Kg/cow) & $6.14 \pm 0.18^{a}$ & $6.58 \pm 0.14^{\mathrm{a}}$ & $7.60 \pm 0.22^{b}$ & $7.93 \pm 0.28^{b}$ \\
\hline SNF\% & $8.72 \pm 0.03$ & $8.69 \pm 0.03$ & $8.71 \pm 0.04$ & $8.74 \pm 0.03$ \\
\hline FSNFY (Kg/cow) & $17.08 \pm 0.48^{\mathrm{a}}$ & $18.20 \pm 0.37^{\mathrm{a}}$ & $20.87 \pm 0.59^{b}$ & $21.87 \pm 0.78^{b}$ \\
\hline Total solids \% & $13.07 \pm 0.08$ & $12.87 \pm 0.06$ & $12.94 \pm 0.13$ & $13.08 \pm 0.13$ \\
\hline FTSY (Kg/cow) & $25.51 \pm 0.68^{\mathrm{a}}$ & $26.94 \pm 0 . .55^{\mathrm{a}}$ & $31.25 \pm 0.89^{b}$ & $32.66 \pm 1.14^{b}$ \\
\hline $\mathrm{SCC}\left(10^{5}\right.$ cells $/ \mathrm{ml}$ of milk $)$ & $3.04 \pm 0.29^{\mathrm{a}}$ & $2.72 \pm 0.30^{\mathrm{a}}$ & $2.68 \pm 0.30^{\mathrm{a}}$ & $1.70 \pm 0.11^{b}$ \\
\hline FCMY/TDNI & $1.80 \pm 0.04^{\mathrm{a}}$ & $1.87 \pm 0.04^{\mathrm{a}}$ & $2.06 \pm 0.05^{b}$ & $2.01 \pm 0.05^{b}$ \\
\hline FCMY/CPI & $8.28 \pm 0.15^{\mathrm{a}}$ & $8.35 \pm 0.13^{\mathrm{a}}$ & $9.47 \pm 0.20^{\mathrm{b}}$ & $8.94 \pm 0.18^{b}$ \\
\hline GE \% & $33.42 \pm 0.73^{\mathrm{a}}$ & $34.82 \pm 0.66^{\mathrm{a}}$ & $38.35 \pm 0.90^{b}$ & $37.47 \pm 0.87^{b}$ \\
\hline
\end{tabular}

Treatment means bearing different superscripts within same row differ significantly $(\mathrm{P}<0.05)$ and NS-Non significant $(\mathrm{P}>0.05)$.

FFY, FPY, FSNFY, FTSY -Fortnightly fat, protein, solid not fat and total solids yield TOTFORMY-Fortnightly total milk yield and FFCMY-Fortnightly $4 \%$ fat corrected milk yield, FCMY-4\% fat corrected milk yield and GEGross efficiency. 
Fig.1 Body condition score (BCS) of experimental groups

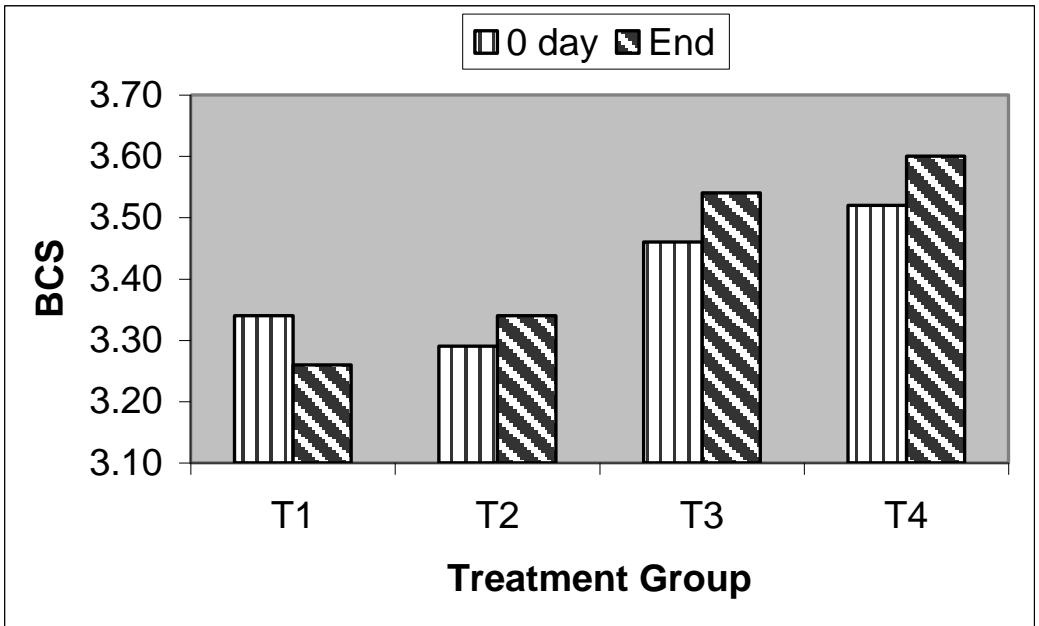

Fig.2 Fortnightly milk production of different treatment groups

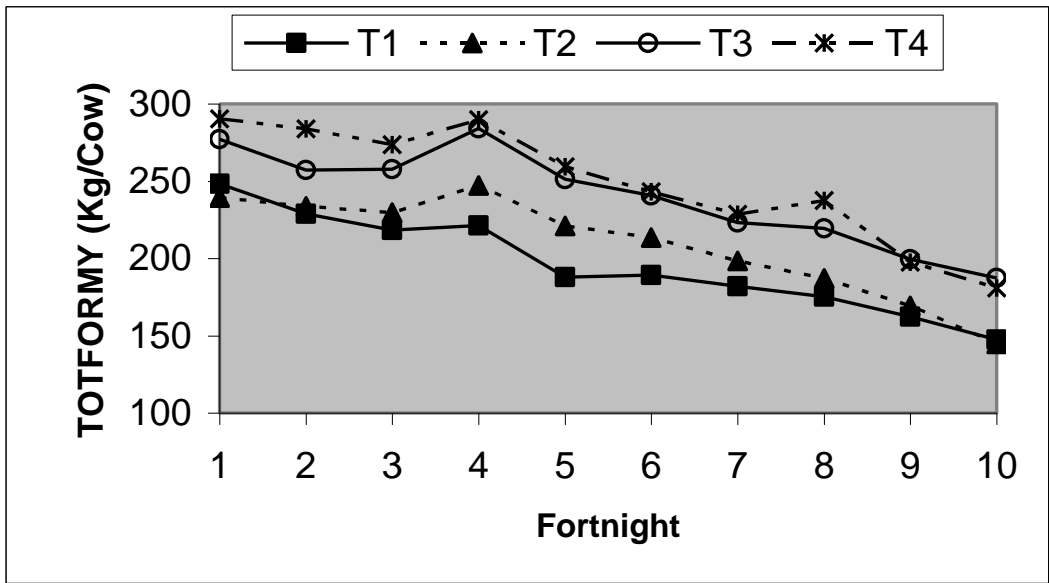

Fig.3 Gross efficiency (GE \%) of different treatment groups

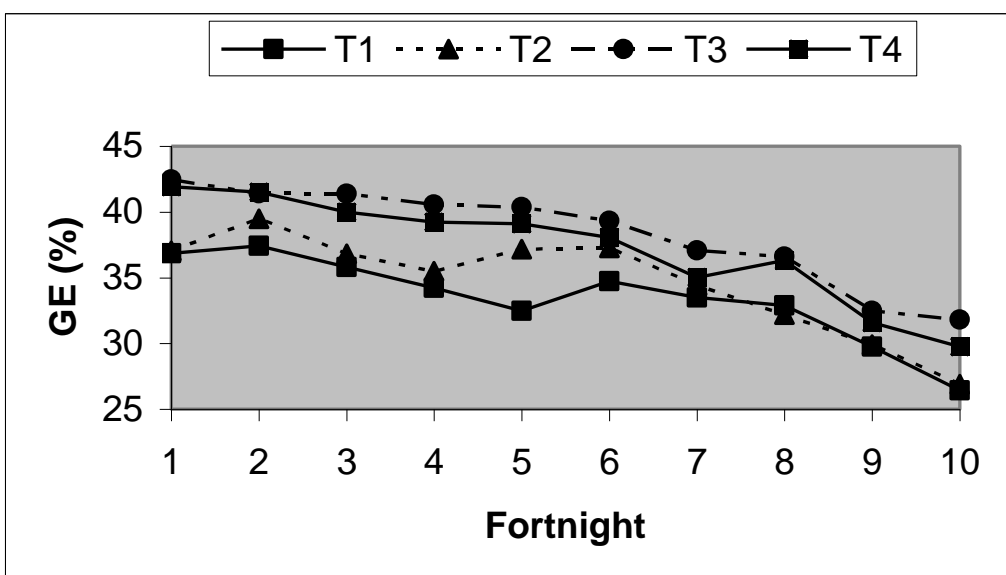


Benefits from sprinkling and fans were reported in a temperate, humid climate (Kentucky), where cows yielded $3.6 \mathrm{~kg}$ more milk (15.9\%) while consuming $9.2 \%$ more feed per day than controls (Turner et al., 1992). Missouri and Israeli work showed milk yield increases of $0.7 \mathrm{~kg} / \mathrm{d}$ in moderate temperatures (Igono et al., 1985) and $2.6 \mathrm{~kg}$ increase in warm, humid conditions (Her et al., 1988). In NDRI, Singh and Aggarwal (2004) reported higher milk yield in crossbred cows provided with fan and mist $(2.12 \mathrm{~kg} / \mathrm{d})$ as compares to control in both hot-humid and hot-dry season.

\section{Somatic cell counts (SCC)}

The study revealed that MC had significant effect $(\mathrm{P}<0.05)$ on SCC. The cows kept under SF showed higher SCC than their counter parts kept under SEC. This difference in SCC may be partly attributed to the decrease in milk yield associated with the elevated level of heat stress. It is not unusual to experience 10 to $20 \%$ decline in milk yield in dairy cattle experiencing heat stress (Shearer and Beede, 1990). Singh and Aggarwal (2004) similar to these findings also reported higher SCC in group of KF cows provided fan $\left(1.54 \times 10^{5}\right)$ as compared to those cows provided fan and mist. Nelson et al. (1969) reported a positive relationship between high summer environmental temperature and SCC in milk.

\section{Efficiency parameters}

The nutrient conversion efficiency to milk (FCMY/TDNI, FCMY/CPI and GE\%) was improved significantly $(\mathrm{P}<0.01)$ due to $\mathrm{EC}$ on the other hand the $\mathrm{F}: \mathrm{C}$ had non significant $(\mathrm{P}>0.05)$ effect on the same (Table 4).

In summer months EC cows were more efficient to convert feed nutrients to milk production. Here, higher concentrate proportion of ration in both shelters gave no added advantage in terms of various efficiency parameters. Further, efficiency of nutrients conversion among treatment groups differed appreciably during early part of lactation only (Fig. 3) and there after these differences got minimized. This may probably be because the animals kept under SF were affected more by heat stress during early phase of lactation when the milk production was at its peak and the metabolic activities were also higher. Shed with fans alone was not sufficient to eliminate overall thermal heat load generated on high producing animals. Heat stress adversely affects the lactational performance of dairy cows principally because the activation of thermoregulatory mechanism of the animal which results in increased RR, HR, reduced feed intake, lower nutrient absorption, and redirection of blood flow from internal to peripheral tissues in an effort to balance heat load (Shearer and Beede, 1990). Heat stressed cows thus tend to expend more energy for maintenance.

In conclusions, provision of fans along with water sprinkling during summer season was proved to be an effective strategy in reducing body temperature, improve feed intake and maintain milk yield at higher level in crossbred cows. Increasing energy density of diet by providing higher concentrate allowances was an effective means to prevent depression of dry matter intake due to heat stress but in isolation it was not sufficient to ensure higher milk production without providing matching microclimate. Higher concentrate allowances in the ration along with effective evaporative cooling systems (T4) was the best strategy to maximize production under hot environmental conditions.

\section{References}

Albright, J.L. and Alliston C.W. 1972. Effects of varying environment upon 
performance of dairy cattle. Journal of Animal Science. 32: 566-577.

AOAC. 1990. Official methods of analysis. Association of official analytical chemists. Washington, D.C.

AOAC. 1995. Official methods of analysis. Association of official analytical chemists. Washington, D.C.

Armstrong, D.V. 1986. Effect of evaporative cooling under a corral shade on reproduction and milk production in a hot arid climate. Journal of Dairy Science. 68 (1): 167.

Armstrong, D.V., Wise, M.E., Torabi, M.T., Wiersma F., Hunter $\mathrm{R}$ and Koper E. 1988. Effect of different cooling system on milk production of late lactation Holstein cows during high ambient temperature. Journal of Dairy Science. 71(Suppl.1): 212 (Abstr).

Berman, A., Folman, Y., Kaim, M., Mamen, M., Herz, Z., Wolfenson, D., A, Aireli and Garber, Y. 1985. Upper critical temperature and forced ventilation effects of high yielding dairy cows in a subtropical climatic. Journal of Dairy Science. 68: 1488-1495.

Brody S. 1945. 'Bioenergetics and Growth'. Reinhold, New York, USA.

Chan., S.C, Huber., J.T, Chen, K.H., Simas, J.M. and $\mathrm{Wu}$ Z. 1997. Effects of ruminally intert fat and evaporative cooling in hot environmental temperatures. Journal of Dairy Science. 80: 1172-1178.

Chen., K.H, Huber J.T, Theurer, C.B., Armstrong, D.V., Wandesly, R.C., Bimas, J.M., Chan, S.C. and Sullivan, J.L. 1993. Effect of protein quality and evaporative cooling on lactational performance of Holstein cows in hot Weather. Journal of Dairy Science. 76: 819-825.

Collier R.J., Doelger, S.G., Head, H.H., Thatcher, W.W. and Wilcox, CJ. 1982. Effects of heat stress during pregnancy on maternal hormone concentrations, calf birth weight and postpartum milk yield of Holstein cows. Journal of Animal Science. 54: 309-319.

Dhiman, T.R., Kleinmans, J., Tessmann, N.J., Radloff, M.D., Pvan, E. and Satter, L.D. 1991. Effects of dietary forage: grain ratio on blood constituents in dairy cow. Journal of Dairy Science. 74: 26912695.

Flamenbaum, I., Wolfenson, D., Kunz, P.L., Maman, M. and Berman, A. 1995. Interactions between body condition at calving and cooling of dairy cows during lactation in summer. Journal of Dairy Science. 78: 2221-2229.

Fuquay, J.W. 1981. Heat stress as it affects animal production. Journal of Animal Science. 52: 164-174.

Fuquay, J.W., Zook, A.B., Daniel, J.W., Brown, W.H. and Poe, W.E. 1979. Modifications in free stall housing for dairy cows during summer. Journal of Dairy Science. 62: 566-577.

Harvey, W.B. 1987. User's Guide for LSMLMW, mixed model least squares and maximum likelihood computer program, PC-I Version, Mimeograph, Ohio State University, Ohio, USA.

Her, E., Wolfenson, D., Flamenbaum, I., Folman, Y., Kaim, M. and Berman, A. 1988. Thermal, productive and reproductive response of high yielding cows exposed to short term cooling in summer. Journal of Dairy Science.71: 1085-1092.

Hsu, SH. and Liu BT. 1996. The influence of stock farm microclimate on the characteristics of dairy cattle milk production (3). Chinese Journal of Agrometrology. 3(2): 105-109.

Igono, M.O., Steevens, B.J., Shanklin, M.D. and Johonson, H.D. 1985. Spray cooling effects on milk production, milk and rectal temperatures of cows during moderate summer season. Journal of 
Dairy Science.68: 979-985.

International Dairy Federation Bulletin. 1984.

Recommendation methods for somatic cell counts in milk. I.D.F. No. 168, pp. 4-6.

Johonson, H.D., Regsdale, A.C., Berrym, IL. and Shanklin, M.D. 1963. TemperatureHumidity effects including influence of acclimation in feed and water consumption of Holstein cattle. Missouri Agricultural Experiment Station Research Bulletein. pp-846.

Mahal, G.S., Randhawa, S.S. and Singh, B. 1997. Effect of feeding different forage to concentrate ratios on nutrient utilization and productive performance of crossbred cows. Indian Journal of Animal Production and Management. 13: 93-97.

Nelson, F.E., Tranmal, H., Schuh, J.D., Wegner, T.N. and Scott, GH. 1969. Criteria of abnormal milk from individual quarters during period of high temperature. Journal of Dairy Science. 52: 912.

NRC. 1989. Nutrient requirement of Dairy Cattle. $6^{\text {th }}$ revised edition. Natl. Acad. Press, Washington, D.C.

Parvinder, S. 1997. Feeding management studies on green forage proportions in the rations of lactating crossbred cows. Ph.D. Thesis. NDRI. (Deemed University), Karnal, Haryana, India.

Prasad, S. 1994. Body condition scoring and feeding management in relation to production performance of crossbred cows. Ph.D. Thesis. NDRI (Deemed University), Karnal, Haryana, India.

Ravagnolo, O., Misztal, I. and Hoogenboom, G. 2000. Genetic component of heat stress in dairy cattle and development of heat index function. Journal of Dairy Science. 83: 2120-2125.

Ryan, D.P., Boland, M.P., Kopel, E., Armstrong, D., Munykazi, L., Godke, R.A. and Ingraham, R.H. 1992.
Evaluating two different evaporative cooling management systems for dairy cows in hot, dry climate. Journal of Dairy Science. 75: 1052-1059.

Sastry, GA. 1978. Clinical veterinary pathology. 2nd Edn. CBS Publishers and Distributors, Delhi.

Shearer, J.K. and Beede, D.K. 1990. Effects of high environmental temperature on production, reproduction, and health of dairy cattle. Agrculturei-Practioner. 11(5): 6.

Singh, M. and Aggarwal, M. 2004. Effect of modified management on milk production and somatic cell count. XXXIII Dairy Industry Conference (26$28^{\text {th }}$ September, New Delhi). Pp-90.

Sprondly, R. 1986. Intake and production response of dairy cows to a fixed ratio of silage to cereals, fed as separate feeds, blended or ensiled together. In: Ensiling of blended grass and grain and its utilization by dairy cows. Report 155, Dept. of Animal Nutrition and Management, Swedish University of Agricultural Sciences, Uppsala, Sweden.

Strickland, J.T., Bucklin, R.A., Nordstedt, R.A., Beede, D.K. and Bray, D.R. 1988. Sprinkling and fan evaporative cooling for dairy cattle in Florida. ASAE. Paper 88-4042, Amer. Soc. Agric. Engr. Rapid City. Pp-12.

Sutton, J.D. 1989. Altering milk composition by feeding. Journal of Dairy Science.72: 2801.

Tarzon, M., Huber, J.T., Meena, H., Nusso, L. and Nussio, C. 1999. Effects of bovine somatotropin and evaporative cooling plus shade on lactaional performances of cow during heat stress. Journal of Dairy Science. 82: 2352-2357.

Taylor, R.B., Huber, J.T., Gomez-Alarcon, Wiersma, F. and Pang, X. 1991. Protein degradability and evaporative cooling on performances of dairy cows during 
hot environmental temperature. Journal of Dairy Science. 74: 243.

Thomas, P.C. and Martin, P.A. 1988. The influence of nutrient balance on milk yield and composition. In 'Nutrition and lactation in the dairy cow'. Philip L. Cransworthy (Ed), Butterworth, London, pp, 97-132.

Turner, L.W., Chastain, J.P., Hemken, R.W., Gates, R.S. and Crist, WL. 1992. Reducing heat stress in dairy cows through sprinkler and fan cooling. Applied Engineering Agriculture. 8(2): 251-256

Tyrell, H.F. and Reid, J.T. 1965. Production of energy value of cow's milk. Journal of Dairy Science.48:1215-1223.

Wardeh, M.F. 1981. 'Models for estimating energy and protein utilization for feeds. Ph.D. Dissertation, Utah State Univ. Logan.

\section{How to cite this article:}

Chittapriya Ghosh, Shiv Prasad, Sanjoy Datta, Dulal Chandra Roy, Amitava Roy, Shyam Sundar Kesh and Nirmal Kumar Tudu. 2018. Effect of Cooling and Concentrate Feeding on Performances of Karan Fries Cattle under Loose Housing System. Int.J.Curr.Microbiol.App.Sci. 7(12): 2657-2670. doi: https://doi.org/10.20546/ijcmas.2018.712.302 